\title{
The origins of the state: technology, cooperation and institutions
}

\author{
Giacomo Benati $^{1}$ (D) and Carmine Guerriero ${ }^{2 *}$ \\ ${ }^{1}$ Faculty of Economics and Social Sciences, Eberhard Karls Universität Tübingen, Tübingen, Germany and ${ }^{2}$ Department of \\ Economics, University of Bologna, Bologna, Italy \\ *Corresponding author. Email: c.guerriero@unibo.it
}

(Received 2 June 2020; revised 29 October 2020; accepted 2 November 2020)

\begin{abstract}
We develop a theory of state formation shedding light on the rise of the first stable state institutions in Bronze Age Mesopotamia. Our analysis suggests that the mix of adverse production conditions and unforeseen innovations pushed groups favored by old technologies to establish the state by granting political and property rights to powerless individuals endowed with new and complementary skills. Through these reforms, the elite convinced the nonelite that a sufficient part of the returns on joint investments would be shared via public spending and, thus, to cooperate and accumulate a culture of cooperation. Different from the main alternative theories, we stress that: (1) group formation is heavily shaped by unforeseen shocks to the returns on both risk-sharing and innovation; (2) complementarity in groupspecific skills, and not violence, is key determinant of state formation; (3) military, merchant and, especially, religious ranks favored state formation and culture accumulation.
\end{abstract}

Key words: Culture of cooperation; geography; group formation; state formation; technology

JEL classification: O13; H10; D23; D72

'The state comes into existence for the sake of life and continues to exist for the sake of good life' - Aristotele, Politica, 1252b 28-1253a 29

\section{Introduction}

The central question of social sciences is how the state's institutional capacity to provide public goods and incentivize risk-sharing and innovation arises. Despite the relevance of this issue (Acemoglu and Robinson, 2012; Boix, 2015; North et al., 2009), we still lack an organic and empirically sound theory of the determinants of the distribution of power among social groups and their incentives to share it for the purpose of economic cooperation. To help fill this gap, we build on a growing literature on the institutional roles of the elite's inability to commit to direct transfers and the complementarity in group-specific skills (Benati et al., 2020; Boranbay and Guerriero, 2019), and we develop a theory of state formation shedding light on the rise of the first stable state institutions in Bronze Age Mesopotamia.

Our key tenet is that the mix of adverse production conditions and unforeseen innovations pushed groups favored by old technologies to establish the state by granting political and property rights to powerless individuals endowed with new and complementary skills. We identify a more inclusive political process with a stronger nonelite's control over tax policies, whereas we define the nonelite's private rights to land as the probability that a dispossessed plot is given back. This probability is higher

(c) Millennium Economics Ltd 2020. This is an Open Access article, distributed under the terms of the Creative Commons Attribution licence (http://creativecommons.org/licenses/by/4.0/), which permits unrestricted re-use, distribution, and reproduction in any medium, provided the original work is properly cited. 
the wider the range of available legal remedies is, the more efficient their public enforcement is and the easier alienability is (Benati et al., 2020; Guerriero, 2019). ${ }^{1}$ Through reforms toward stronger political and property rights, the elite convinced the nonelite that a sufficient part of the returns on joint investments would be shared via public spending and, thus, to cooperate and accumulate a culture of cooperation, i.e. an internalized reward from cooperating in economic activities (Benati et al., 2020; Boranbay and Guerriero, 2019). This cultural accumulation helped the nonelites credibly commit to cooperate despite their limited incentives to participate in investment due to the small expected public spending.

Our model implications are consonant with the economic and institutional evolution of Bronze Age Mesopotamia. ${ }^{2}$ First, the drought - i.e. cold and dry spans (Weiss, 2017: 94) - of the end of the urban revolution period (3800-3300 BCE) magnified consumption risk and the value of irrigation infrastructures. The consequent need of organizational skills favored the passage of decision-making power from the landholders to the religious leaders. Thanks to this new role, the temples gained, over the proto-states period (3300-3100 BCE), the control over public good provision. Moreover, they proposed norms of cooperation in exchange for guidance on how to share consumption risk. Second, the arid conditions of the onset of the city-states period (3100-2550 BCE) reduced the farming returns forcing the religious households to share their power with rising military ranks, who engaged a larger population share in farming by offering tenure-for-service contracts in exchange for the participation in stable armies. Conscripted workers enjoyed redistribution and risk-sharing activities. Third, the milder climate of the kingdoms period (2550-2350 BCE) relaxed the elites' need to share their power. Fourth, an extended period of inclement climate, and the consequent rise of long-distance trade as an alternative to farming, pushed, over the empires period (2350-1750 BCE), the religious and palatial elites of the polities foreseeing the largest returns on long-distance trade to involve the merchants in policy making and produce trade-related public goods. Finally, over the entire period, adverse climate shocks were accompanied by reforms toward stronger farmers' rights to land.

Our analysis is related to the three main strands of the vast literature on state formation. First, we share with North and Weingast (1989), Barzel and Kiser (1991), Fleck and Hanssen (2006) and Myerson (2008) the idea that elites enact more inclusive political institutions and a stronger protection of the nonelites' property rights on inputs because unable to incentivize them by committing to direct transfers. As Boranbay and Guerriero (2019) and Benati et al. (2020), we stress that fiscal policies are key commitment devices in the elites' hands. Second, we endorse Boix's (2015) vision that unforeseen shocks are the main determinants of the initial distribution and the consequent evolution of decisionmaking power. Boix (2015), however, speculates that technological innovations matter only if they limit skill heterogeneity and, thus, convince either the producers to invest in defensive structures against looters or the looters to limit plunder in exchange for continuous flows of rents, whereas we show that the true engine of economic and institutional evolution is the complementarity in group-specific skills. To elaborate, shocks endowing the nonelites with skills complementary to those of the elites encourage the latter to share their power to foster inter-group cooperation in the face of adverse production conditions. Finally, we point to the limited role of violence. Well-known alternative theories of state formation suggest that either the elites expand the nonelites' political rights if intimidated by possible unrest or that the most rudimental institutional limit to violence is the armed peace among elites employing religious, military and merchant ranks to organize the production of rents by the rest of the population (Acemoglu and Robinson, 2012; North et al., 2009). Our analysis implies, instead, that these ranks arose because of unforeseen innovations and, in the

\footnotetext{
${ }^{1}$ This definition is not only consonant with Alchian's (1965) classic view that property rights are those of 'individuals to the use of resources' but also avoids the confusion between likelihood and value of usage inherent in the Barzel's (1994) conceit that they correspond to the expected stream of net utility. More generally, our approach subsumes the devalued role of legal rights (Hodgson, 2015) as well as the insights of the endogenous private rights literature (Guerriero, 2016).

${ }^{2}$ We label with: (1) 'Lower' ('Upper') Mesopotamia the regions of Southern (Northern) Iraq and Southwestern Iran (Northern Israel, Northeastern Syria and Southeastern Turkey); (2) proto(city)-states period the Late Uruk (Jemdet Nasr and Early Dynastic) era(s); (3) kingdoms (empires) period the Pre-Sargonic (Akkadian, Ur III and Old Babylonian) era(s).
} 
aftermath of adverse shocks to the production conditions, gained political and property rights. This power encouraged them to exchange their - culture of - cooperation in investment for public good provision, eventually turning them into a part of the elites.

Our paper delivers three contributions. First, we develop a theory of state formation grounded in the elites' time-inconsistency issues and the complementary in group-specific skills clarifying which shocks to the returns on both risk-sharing and innovation shape state formation. Second, we evaluate the implications of our framework by studying the rise of the first stable state institutions in human history. To elaborate, not only do we buttress the effort of a growing strand of historical and anthropological research to debunk the idea that early states were dominated by elites relying only on violence to co-opt workers and reduce conflicts (Blanton and Fargher, 2016; Frangipane, 2017; Richardson, 2011; Richardson and Garfinkle, 2020; Steinkeller and Hudson, 2015; Yoffee and Seri, 2019), but we also draw social scientists' attention to a unique and understudied historical data set. ${ }^{3}$ Different from similar databases on medieval and modern societies, this sample displays large variation across time and space on economies sufficiently simple to credibly link geography to institutions and demarcated by narrow and stable boundaries (Benati et al., 2020). Finally, we emphasize the need to clarify the origins of specialized classes to avoid confusing rent-seeking with cooperation.

The paper proceeds as follows. In section 2, we review four historical facts consonant with the central implications of the theoretical framework, which we illustrate in section 3. Here, we also compare our ideas with those of the alternative theories of state formation. We conclude in section 4 .

\section{The origins of the state in Bronze Age Mesopotamia: stylized facts}

The facts about Bronze Age Mesopotamia consistent with our theory are: [a] group formation is heavily shaped by unforeseen shocks to the returns on risk-sharing and innovation (see Table 1); [b] complementarity in group-specific skills is key determinant of state formation; [c] military, merchant and, especially, religious ranks favored reforms toward stronger nonelites' rights and the spread of a culture of cooperation and [d] access to violence is not a crucial institutional engine. ${ }^{4}$

Urban revolution (3800-3300 BCE) - Characterized by limited political and cultic leadership, population density and long-distance trade (Liverani, 2014: 44), Mesopotamia gradually developed, over the fourth millennium BCE, the first forms of state institutions (Liverani, 2014: 43-45). To start with, the cooler and drier conditions of the second half of the fourth millennium BCE induced the collapse of the early urban sites in Upper Mesopotamia (McMahon, 2020: 21-24; Ristvet, 2017: 38) and the drying up of the marshy alluvium in Lower Mesopotamia (Riehl et al., 2014: 3; Weiss, 2017: 95-96). In the Alluvium, in particular, the combination of the smaller water supply and the mismatch between the rivers' flows and the agricultural cycles magnified the returns on both artificial irrigation and the organizational skills necessary for their construction and maintenance (Altaweel, 2019; Brooke, 2014: 203). These precious inputs were provided by religious figures who gained, thanks to their cultic leadership, an increasing power over both the exploitation of economic resources and political decision-making [a] (Liverani, 2014: 58; Steinkeller, 2019: 113). ${ }^{5}$

Proto-states period (3300-3100 BCE) - These innovations eased the establishment of the temple as the first institutionalized decision-maker $[\mathbf{b}]$. Through the command of levee-slope irrigation (Wilkinson et al., 2015: 412-413), religious elites gained from the landholding groups increasingly larger estates that were assigned initially to hired workers and, later on, to tenured farmers in exchange

\footnotetext{
${ }^{3}$ Two prominent contributions to this older line of research are Childe (1936) and Liverani (2006). The former claims that the elites blocked technological progress and, in turn, cultural evolution, whereas the latter envisions that the temples appropriated estates from former landholding groups, such as village communities, through coercive or ideological means.

${ }^{4}$ More details on the evolution of the micro-mechanisms of decision-making are reported in Benati and Guerriero (2020), whereas more information on the single polities is illustrated in the Internet appendix accompanying Benati et al. (2020).

${ }^{5}$ Although simpler forms of irrigation are observed from the fifth millennium BCE (Rost, 2017: 8; Wilkinson et al., 2015: 408), the droughts of the fourth millennium BCE pushed the institutionalized decision-makers to combine this experience and their skills in organizing mass labor to construct complex artificial systems (Hole, 1994: 138).
} 
Table 1. Technology, cooperation and institutions

\begin{tabular}{cccc}
\hline Timeline (BCE) & Climatic shocks & Innovations & Institutional discontinuities \\
\hline $\begin{array}{c}\text { 3800-3100: urban } \\
\text { revolution and } \\
\text { proto-states period }\end{array}$ & $\begin{array}{c}\text { Increasingly } \\
\text { cold and dry }\end{array}$ & $\begin{array}{c}\text { Canals; animal-driven } \\
\text { plow; writing; } \\
\text { viticulture in the North }\end{array}$ & $\begin{array}{c}\text { Organizational role of priests } \rightarrow \\
\text { Temple as institutionalized } \\
\text { decision-maker }\end{array}$ \\
\hline $\begin{array}{c}\text { 3100-2550: } \\
\text { City-states period }\end{array}$ & Droughts & $\begin{array}{c}\text { Copper weapons; } \\
\text { fortifications; } \\
\text { viticulture in the North }\end{array}$ & $\begin{array}{c}\text { Tenure-for-service agreements and } \\
\text { conscripted army } \rightarrow \text { Palace as } \\
\text { institutionalized decision-maker }\end{array}$ \\
\hline $\begin{array}{c}\text { 2550-2350: } \\
\text { kingdoms period }\end{array}$ & Optimum & $\begin{array}{c}\text { Seeder plow; war-cart; } \\
\text { tin-bronze weapons }\end{array}$ & $\begin{array}{c}\text { Rising farming returns and } \\
\text { warfare } \rightarrow \text { Supremacy of palace }\end{array}$ \\
\hline $\begin{array}{c}\text { 2350-1750: empires } \\
\text { period }\end{array}$ & Droughts & $\begin{array}{c}\text { Tin-bronze tools; } \\
\text { viticulture in the } \\
\text { South }\end{array}$ & $\begin{array}{c}\text { Long-distance trade } \rightarrow \text { Merchants as } \\
\text { institutionalized decision-maker }\end{array}$ \\
\hline
\end{tabular}

Note: The main innovations are given in bold.

for corvée and/or a share of the produce (Adams, 1981: 246; Cripps, 2007: 27; Englund, 1998: 176181; Renger, 1995: 272-278; Steinkeller, 1999: 291-292). Hired workers remained powerless, whereas allotting gradually imposed de facto property rights for tenured farmers [b] (Cripps, 2007: 23; Wilcke, 2007: 25-26). Crucially, the temples not only extended their control over vital public tasks like gathering taxes, managing civil engineering projects [c], supporting short-distance trade, animal husbandry and craft activities (Matthews and Richardson, 2018: 723), but they also proposed norms of cooperation in exchange for guidance on how to share consumption risk. To illustrate, religious households stored perishable goods, supplied grain in times of famine, accommodated loans to those in need and regulated interest rates (Charpin, 2017; Liverani, 2014: 61-82).

City-states period (3100-2550 BCE) - The North-South divide was amplified by the 3200-2800 BCE droughts (Riehl et al., 2014: 2-3). The rain-fed zones reverted to the village-based organization, and agricultural returns fell in the Alluvium (Liverani, 2014: 89; Ristvet, 2017: 38-40). This last shock pushed the religious households to share, from $2850 \mathrm{BCE}$ on, their political power with rising military leaders [a], who had left the temple to establish the palace (Staubwasser and Weiss, 2006: 379-380; Steinkeller, 2019: 122-123). These palatial ranks involved a large share of the population in the farming activities by offering land-tenure agreements in exchange for their participation in civil engineering projects and the military [c] (Cripps, 2007: 12-15, 19-20). Conscripted workers received unique benefits [d], i.e. foodstuffs, clothing, access to irrigation and draft animal power in times of peace and the booty after military victories (Richardson, 2011: 17-36; Steinkeller, 2018: 10-11). Meanwhile, in Upper Mesopotamia, the post-2700 BCE climatic improvements triggered urbanization, first, and the empowerment of both the extended royal family and religious and elders' councils, later [a, b] (Ristvet, 2017: 40). Land tenure was organized as either owner-operated farming under de facto property rights or direct cultivation via hired laborers and sharecroppers (Widell et al., 2013: 63-64). Stronger political and property rights were accompanied by a larger provision of public buildings and conscripted armies [b] (Rey, 2016).

Kingdoms period (2550-2350 BCE) - Thanks to the increased farming returns assured by the milder climate and the expansion of inter-state warfare (Richardson, 2011: 18; Ristvet, 2017: 41), the palaces acquired executive supremacy, which they affirmed by bringing temple assets under palatial purview in the Southern polities and by embedding the elders' councils and the religious life within the palace in Upper Mesopotamia [a, b] (Liverani, 2014: 99, 114, 122). In the Alluvium, moreover, tenured landholdings became heritable and eventually alienable [b] (Cripps, 2007: 70-77; Wilcke, 2007: 26-27, 67-70). This trend toward stronger farmers' rights was seemingly aided by the spread of the domesticated grapevine into Upper Mesopotamia, first, and Lower Mesopotamia, later [a] (Miller, 2008; Powell, 1996). Because of the mix of its pivotal role in cultic and social rituals and the opacity of its production process, wine became a standard diplomatic gift exchanged among neighboring elites 
(Barjamovic and Fairbairn, 2018; Benati, 2016: 156-157; Powell, 1996: 103-112), constituted a difficult-to-appropriate resource and empowered its producers (Dietler, 2005). The combination of the aforementioned shocks to private rights pushed the elites of the major polities to provide public and ritual buildings, irrigation infrastructures and both conscripted and professional armies [d] (Hamblin, 2006: 48-72; Liverani, 2014: 99, 108-109; Rost, 2017: 9-10).

Empires period (2350-1750 BCE) - After having consolidated their control on the Alluvium, the Akkadian kings conquered large portions of the Fertile Crescent (Sallaberger and Schrakamp, 2015: 105-112). The Southern polities were turned into tributary provinces, whereas the other annexed territories were managed by appointed governors assisted by military and bureaucratic functionaries and local elites (Foster, 2016: 39-44). The colder and drier spell that hit the entire region, peaking between 2200 and $1900 \mathrm{BCE}$, induced the expansion of de jure farmers' rights to the land directly controlled by the crown [b] (Wilcke, 2007: 70-72), and, ultimately, drove the collapse of the Akkadian state (Cookson et al., 2019). After a phase of political fragmentation, the Ur III kings were able to reunify much of Mesopotamia between 2120 and 2000 BCE (Liverani, 2014: 155-161). They divided their empire into core provinces administered by co-opted governors and peripheral regions controlled by military officials and crown functionaries, who gained in exchange large estates (Garfinkle, 2013). The peasants, instead, received land in exchange for corvée and, even if the plots were inalienable, their de facto property rights were enforced [b] (Liverani, 2014: 197-198). A series of new droughts contributed to the collapse, around $2000 \mathrm{BCE}$, of the Ur III kingdom in Lower Mesopotamia (Yoffee, 2005: 145-146) and to population decline and political instability in Upper Mesopotamia (Ristvet, 2017: 49). This void was exploited by the semi-nomadic Amorites, which, over the period 2000-1850 BCE, subjugated several independent polities (Liverani, 2014: 175-181). To manage this fragmented landscape, the Amorite kings were forced to negotiate with both tribal leaders and urban-based councils and to offer to the population tenured and safe land in exchange for military service [b] (Fleming, 2004; Liverani, 2014: 224; Ziegler, 2008: 50). More important, the falling farming returns (Weiss, 2017: 105-111, Fig. 3.3), together with the diffusion of metal tools in almost all households, determined a trade revolution that, from $2000 \mathrm{BCE}$, eased the formation of a new exchange landscape organized around two interlocking circuits [a] (Barjamovic, 2018: 121-125): i.e. the Old Assyrian network carrying textiles and tin from Ashur to Kanesh and bringing back precious metals (Barjamovic, 2018: Figs. 5.1 and 5.2) and the Old Babylonian network mobilizing metals and textiles between Shush and Hazor (Liverani, 2014: Fig. 12.4).

In contrast to previous exchange circuits, which were organized by both institutional agents and merchant families, the second millennium long-distance trades were dominated by private traders who were able to accumulate an increasing political power [b, c] (Barjamovic, 2018; Liverani, 2014: 163, 190, 212-218; Van De Mieroop, 2015: 89-92; Yoffee and Barjamovic, 2018). To illustrate, temples and palaces of the polities foreseeing the largest payoff from long-distance trade empowered the traders willing to incur the transportation risk by substituting their guilds for the former Ur III administrative sector [b, c] (Barjamovic, 2018: 123-124; Postgate, 1992: 221). As a result, the palatial and temple ranks of Ashur, Emar, Sippar and Tuttul ruled together with merchant councils and supported limited customs and the provision of trade-related public goods, i.e. secured trade routes and interpolity exchange agreements (Barjamovic, 2018: 123-128; Palmisano, 2018: 22). This trade revolution was accompanied by stronger tenants' rights, edicts remitting debts and renewed provision of public buildings and both conscripted and professional armies [c, d] (Liverani, 2014: 187-188; Richardson, 2011: 21-32; Westbrook, 2003: 362-407). Only the accession to the Babylonian throne of Hammurabi, who unified the Alluvium in 1755 BCE, blocked these dynamics, empowering the 'palace [at] the expenses of the private sector [and] temple' (Liverani, 2014: 242).

\section{Theoretical framework}

We rely on a growing literature on the institutional roles of the elites' time-inconsistency issues and the complementary in group-specific skills to formally rationalize these four stylized facts. 


\subsection{A theory of technology, cooperation and institutions}

Benati et al. (2020) consider the relationship between an elite - she - and a nonelite - he - trying to cooperate in either a farming or long-distance trade. The elite initially owns the untaxed output and the input - i.e. either the land or the control over the commercial routes, whereas the nonelite can employ the input to deliver a valuable product by incurring a costly investment and provided that the imperfectly observable geographic conditions are 'favorable', e.g. the land and the temperature are sufficiently suitable for cultivation or the trading risks are sufficiently small. The interaction between elite and nonelite should be envisioned between any two consecutive and unforeseen technological shocks, each endowing the nonelite with a new technology and leaving to the elite the initial control over both scarce resources and institutional design (Benati et al., 2020). ${ }^{6}$ The evolution of the political process implies that the identity of the elites may change across technological eras.

To incentivize investment, the elite cannot commit to direct transfers, but she can lean on two other instruments. First, she can grant the nonelite a more inclusive political process, which allows him to select both the tax rate and his preferred public good. Second, she can punish the nonelite for suspected shirking by evicting him and, thus, zeroing his future payoffs from public good consumption. ${ }^{7}$ This 'stick' is also costly for the elite, who needs to substitute the nonelite. When the expected investment return is small, the nonelite cooperates only under full property rights and the more inclusive political institution allowing him to fully tax the output and produce his preferred public good. As shown by Boranbay and Guerriero (2019), this process is eased by the nonelite's accumulation of a culture of cooperation. Intuitively, a large implicit reward from cooperating credibly signals to the elite the nonelite's commitment to cooperate even in activities delivering a small return and, thus, a tiny value of public spending. When, instead, the expected investment return is intermediate, the elite does not need to give up her preferred public good and accept full taxation to convince the nonelite to participate. Then, she keeps control over fiscal policies and the tax rate falls with the investment return. Yet, the nonelite's property rights must be complete since his individual rationality constraint is more stringent than his incentive compatibility constraint and punishment can be avoided when it discourages participation. When, finally, the investment return is large, the elite can also weaken the nonelite's property rights. Embracing the stick, however, is optimal only if production is sufficiently transparent, and, thus, punishment effectively disciplines a shirking nonelite. ${ }^{8}$

Three are the implications of Benati et al.'s (2020) and Boranbay and Guerriero's (2019) models key for understanding state formation (see Figure 1). First, the identity of each group should be logically seen as determined by unforeseen shocks granting to the nonelite skills complementary to those of the elite. Second, a limited expected investment return favors both reforms toward stronger political and property rights and the nonelite's cultural accumulation, whereas the opacity of the production process is only related to private rights. Finally, the nonelite's expected utility from public good consumption rises with the strength of his rights. The narrative evidence in section 2 matches these predictions. ${ }^{9}$

On the one hand, organizational, military and production innovations endowed the nonelites with skills complementary to those of the elites. The latter were the landholders during the urban revolution

\footnotetext{
${ }^{6}$ Formally, one could envision that, at the end of any such interaction, there is an unforeseen contingency assigning to a subgroup of the powerless population skills complementary to those of the elite and essential to successfully finalize a joint investment activity and none of the main model implications will change (Boranbay and Guerriero, 2019: 9).

${ }^{7}$ The private rights' value for the nonelite is, then, the future public good consumption payoff assured by tenure security.

${ }^{8}$ Like the opacity of production, also the institutions designed to tackle it, and, notably, governmental hierarchy (Ahmed and Stasavage, 2020), would cover, in our model, a second-order role in state formation. Consistent with this view and contrary to the dichotomy between hierarchical and corporate societies hypothesized by much of the archeological and anthropological literature (Smith et al., 2018: 5-6), bureaucracy and centralized resource control appeared during the Late Neolithic, expanded during the proto-states to empires periods and shrank, without vanishing, with the subsequent rise of more inclusive political institutions (see Benati and Guerriero, 2020; Frangipane, 2018: 10-11; Yoffee and Barjamovic, 2018).

${ }^{9}$ Building on a panel of 44 major Mesopotamian polities spanning the 3050-1750 BCE period, Benati et al. (2020) report OLS estimates consistent with these predictions. These results stand even after controlling for environmental circumscription, which is the difference between the productivity of the polity core and that of the surrounding areas. Intuitively, a lower outside option should discourage exit and favor both taxation and less inclusive political institutions (Carneiro, 1970).
} 


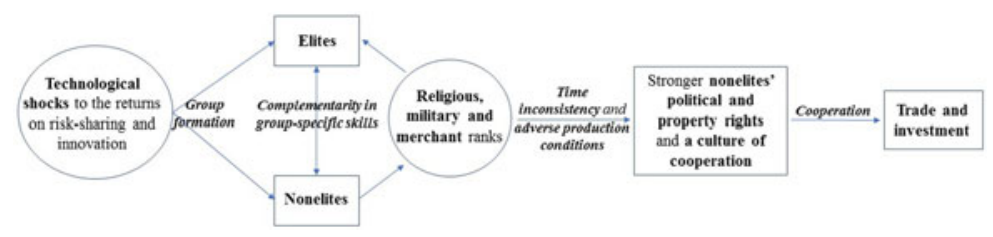

Figure 1. Testable implications of the theoretical framework. Note: The main ingredients of the theoretical framework are given in bold.

period, religious ranks during the proto- and city-states periods and the temples and palaces during the kingdoms and empires periods, whereas the role of the former was covered by the temples during the urban revolution period, military ranks during the city-states period and merchants during the empires period (Sallaberger, 2019). On the other hand, shocks reducing the returns on joint investments forced the elites to grant to the nonelites strong political and property rights to credibly favor the exchange between their - culture of - cooperation in investment and public good provision.

During the proto-states period, fierce droughts combined with the temple's ability to organize irrigation infrastructures pushed the landholding groups to entrust religious ranks with the control over the arable land and a rising decision-making power. As a result, the landholders gained corvée and/or a share of produce otherwise unattainable, whereas tenured farmers enjoyed the unprecedent provision of public interest goods and risk-sharing activities, which, in turn, fostered their cultural accumulation. Turning to the city-states era, the worsening of the climatic conditions, together with the prospect of a novel form of tenure-for-service agreement assuring the access to the unique benefits of a conscripted army, persuaded the temple to share with the palace the power of organizing land exploitation and public good provision. Similarly, during the kingdoms era, the improved climatic conditions helped the palace gain an edge over the temple, whereas the spread of viticulture contributed to the expansion of the farmers' rights to land in the communities most involved in this very opaque activity. Finally, at the beginning of the second millennium, the mix of prolonged droughts and the diffusion of metals convinced the religious and palatial ranks to empower the merchants. The former gained part of the returns on long-distance trades, whereas the latter acquired the power of managing port quays, gathering customs, and producing trade-related public goods.

At this point, it is instructive to compare the conclusions of our theoretical and anecdotal analyses with those of three main alternative theories of state formation (Acemoglu and Robinson, 2012; Boix, 2015; North et al., 2009), taken for granted the need for further interdisciplinary research on the micro-mechanisms underlying the interplay among violence, technology, group formation and institutional evolution.

\subsection{Us and them: has violence a relevant institutional role?}

Despite all three frameworks assign a central role to violence, its empirical impact in Bronze Age Mesopotamia was limited. Notably, the numbers of internal and external conflicts neither affect the baseline Benati et al.'s (2020) estimates nor display significant coefficients. This pattern is consonant with the absence of the mechanisms through which violence matters in the alternative theories.

\subsubsection{Acemoglu and Robinson (2012)}

Starting with the Acemoglu and Robinson's (2012) mantra that democratization is intimately linked to the risk of nonelites' unrest, not one internal conflict, over the two millennia considered in our analysis, ended up in a successful institutional revolution. To elaborate, the first noticeable uprisings go back to the Akkadian period, when Sargon's successors had to face revolts of formerly independent Southern polities (Foster, 2016: 7-8, 12-14). These revolts were easily crushed, and the Akkadian empire endured (Yoffee and Seri, 2019: 189). A more substantial record of internal conflicts emerges 
with the collapse of the Ur III dynasty and the uneasy coexistence of the new Amorite monarchs with local powers (Richardson, 2012: 16-25; Yoffee and Seri, 2019: 190). Yet, virtually all 63 rebellions of the Old Babylonian period were crushed (Richardson, 2011: 26-33; Richardson, 2016; Yoffee and Seri, 2019: 190-191). Overall, civil conflicts weakened early states without shaping institutions. ${ }^{10}$

\subsubsection{North et al. (2009)}

North et al. (2009) foresee two main political transitions. First, a shift from a state of nature marked by chaotic interactions to a 'natural state' limiting violence via self-enforcing, incentive-compatible agreements among armed elites. The elites share the rents created by the exploitation of resources by nonelites subjugated through patronage relationships, which, in turn, are inherently fragile. Second, a shift from natural states to 'open access' social orders grounded in the centralization of violence in the hands of the military and the balance between political and economic competition. There are three key stylized facts about Bronze Age Mesopotamia inconsistent with this view.

First, the elites did not typically possess their own armies and, ${ }^{11}$ even under the less inclusive political institutions characterizing the proto-states and kingdoms periods, the military power was centralized. Archeological remains, indeed, indicate that the extremely costly bronze weapons were available only to political leaders (Wischnewski, 2017). To illustrate, the palace households of both Ebla and Lagash authorized the production of metal weapons only within the palace and entrusted them to conscripted soldiers only during battles (Archi, 2010: 16-20; Schrakamp, 2010: 7-9). Finally, bronze weapons and carts were only found in those graves of the Royal Cemetery of Ur (2550-2450 BCE) associated with the royal elite (Hamblin, 2006: 49; Schrakamp, 2010: 8-9).

Second, the idea that main concern of the elites of the early natural states was to establish patronage relationships to control violence is misleading (Richardson, 2016: $50 \mathrm{n}$. 87; Wilcke, 2007: 117-120). Consistent with our theoretical framework instead, their biggest worry was to recruit nonelites and convince them to cooperate in joint investment activities (Richardson, 2012: 29). Royal deeds, indeed, often dealt with piety, civic works and public good provision and the first forms of legal rules regulated access to arable land by enacting increasingly stronger nonelite's private rights (Richardson, 2016: 4850). To elaborate, the religious households' land was the first to be protected around $3000 \mathrm{BCE}$ by de jure property rights, enforced through written land deeds (Wilcke, 2007: 20-69). With the rise of the service-for-tenure system, then, de facto property rights were granted to tenured farmers as well (Cripps, 2007: 12-15, 19-20). From the mid of the third millennium BCE, finally, these rights started to be protected in a de jure fashion and plots became transferable (Wilcke, 2007: 69-70, 80-86). These innovations supported the cooperation between the elites and nonelites providing workforce in exchange for a share of the product and public goods (see section 2).

Finally, the intensity of violence seems to be positively related to the inclusiveness of the political process. To illustrate, warfare was limited during the urban revolution and proto-states periods (McMahon, 2014: 176-177), and no evidence of organized external conflicts can be found in the written sources for the period 3100-2600 BCE (Richardson, 2011: 18; Richardson, 2016: 48). It is only after 2600 BCE that violence entered the elites' agenda (Marchesi and Marchetti, 2011: 214-219; Richardson, 2016: 47-49). ${ }^{12}$ Similar conclusions can be drawn from skeletal data, which imply that:

\footnotetext{
${ }^{10}$ This last piece of evidence, but not the fact that democratization prevailed especially because of the mix of adverse production conditions and unforeseen innovations, might be driven by an immediate consequence of the Acemoglu and Robinson's (2012) framework: 'democracy is less likely to consolidate when the elites are landowners' (Acemoglu and Robinson, 2006). Under such a scenario, the elite is more heavily taxed under democracy and suffers more limited damages from coups.

${ }^{11}$ The only exception was during the Early Dynastic and pre-Sargonic periods, when temples could conscript soldiers and high religious elites could act as military generals (Frayne, 2008: 38). More generally, the rulers could always mobilize and directly guide conscripted and professional soldiers linked to the temple households (Schrakamp, 2010: 7-10).

${ }^{12}$ Contrary to Boix's (2015: 131-132, 253-254) claim, the rise of a 'class of individuals with [a] comparative advantage in the use of violence' is undoubtedly attested only after 2700 BCE. Examples of these skills are: (1) large amount of war prisoners created by the campaigns conducted by an unknown ruler between 2600 and 2500 BCE (Steinkeller, 2013); (2) mass
} 
(a) warfare was mostly localized over the borders separating the core and the northern peripheries; (b) the main cause of most traumatic lesions was occasional intra-group violence and (c) violence shrank over the Bronze Age (Garfinkle, 2020: 233; Sołtysiak, 2015: 5-6).

\subsubsection{Boix (2015)}

Finally, our analysis contradicts Boix's (2015) idea that a more inclusive political process requires homogeneous group-specific skills and takes the form of either a state controlled by looters exchanging with producers rents for protection - i.e. 'monarchy' - or a state dominated by producers defending themselves from looters, i.e. 'republic'. The passage from the former to the latter would be eased by the access to less expensive forms of warfare technologies (Boix, 2015: 254). The evidence discussed in section 3.2.1 already excludes the idea that inter-group conflicts were a crucial determinant of state formation, stressing, instead, that its key cause was the need to cooperate in profitable joint activities by groups with complementary skills. Next, we corroborate this conclusion by showing that neither 'monarchies' nor 'republics' existed in Bronze Age Mesopotamia.

First, none of the less inclusive states, which dominated the kingdoms period, looked like Boix's monarchies since they were favored by military specialization, but they were never based on patronage relationships between the palatial ranks - i.e. the looters - and the religious households, i.e. the producers. On the contrary, the palace cooperated with the temple elites in the provision of valuable public goods and with the powerless population in joint farming and trade activities (Adams, 2009; Prentice, 2010; Richardson, 2011; Rost, 2017; Van De Mieroop, 2015). ${ }^{13}$

Second, the more inclusive political orders observed during the city-states and empires periods cannot be connected to any 'democratizing' military technology easing the ability of the productive groups to defend their assets from looters (Boix, 2015: 256). For instance, the more inclusive political orders embraced by Assur, Der, Emar, Eshnunna, Sippar and Tuttul during the empires period were solely aimed at sharing the returns on long-distance trades between merchant households and palatial and temple elites (Barjamovic, 2018: 128; Fleming, 2004: 211-216).

\subsection{Confusing consequences with causes of institutions: religion, military and merchants}

Consistent with our theoretical framework, our historical analysis suggests that religious, military and merchant ranks arose because of unforeseen technological shocks endowing them with skills complementary to those of the existing elites and, in the aftermath of adverse shocks to the production conditions, gained political and property rights. This power encouraged them to exchange their - culture of - cooperation in investment for public good provision, eventually turning them into a part of the elites. The alternative theories of state formation embrace different views.

Although Acemoglu and Robinson (2012) and Boix (2015) agree on the opposite roles of the church and the merchants, whereby only the latter facilitated reforms toward more inclusive political institutions and a market structure rewarding producers, ${ }^{14}$ they have different views of the military. Boix (2015) claims that military techniques advantaging the looters (producers) - i.e. horses (navy) - ease the formation of stable (unstable) monarchical (republican) regimes, whereas Acemoglu and Robinson (2012) consider the army as the keeper of the status quo. Similarly, North et al. (2009) maintain that the military specialists keep their strength 'both to balance one another's power and to overawe their respective clients' (North et al., 2009: 20), whereas 'nonmilitary elites either control or

\footnotetext{
inhumations in the royal cemetery of Ur (Baadsgaard et al., 2011; Richardson, 2016: 55); (3) mass killings and expulsions imposed by the Akkadian kings to the rebellious cities of Sumer around 2250 BCE (Foster, 2016: 6-14). Even when, during the Ur III period, warfare accelerated, violence always concerned external enemies (Garfinkle, 2020: 231-232).

${ }^{13}$ Crucially, over the kingdoms and empires periods, farmers and merchants also received from the palace gifts usually addressed to competing elites (Sallaberger, 2019) and were invited to important festivals (Sallaberger, 2018: 189).

${ }^{14}$ The precondition for this institutional discontinuity would be a violent rebellion and shocks easing the centralization of the use of violence by producers, respectively (Boix, 2015; Tylecote, 2016).
} 
enjoy privileged access to a vital function like religion, production, community allocation of resources, justice, trade, or education' (North et al., 2009: 19-20).

To show the inconsistency between these claims and the evidence on Bronze Age Mesopotamia, we stress that: (1) in the aftermath of adverse shocks to the production conditions, religious, military and merchant ranks have participated in institutional formation, first, as nonelites and thanks to the complementary between their skills and those of the elites and, then, as elites and thanks to their political power; and (2) larger military costs are not consistently related to more autocratic regimes.

\subsubsection{The institutional role of the temple}

During the urban revolution period, priestly figures, able to coordinate public good provision, formed the first 'great organizations' (Benati, 2018: 118-125; Frangipane, 2018: 13; Liverani, 2014: 53, 6263). ${ }^{15}$ In the process of doing so, they supported state formation by spreading a culture of cooperation. On the one hand, they provided guidance on how to share consumption risk to the palatial ranks, first, and the merchants, later (see section 2). On the other hand, they curbed inter-polity conflicts by promoting cultic practices to common deities (Matthews and Richardson, 2018: 21). These activities helped lock the nonelites in the agreements previously reached with the temple. Even if subordinate to the city rulers, the temples continued to be very influential up to the end of the third millennium by providing military aids and/or performing gubernatorial functions during crises (Steinkeller, 2019: 126, 132-133). During the empires period, moreover, the religious elites outsourced economic activities to farmers and private entrepreneurs (Van De Mieroop, 2015: 84). This shift eased the integration of merchants into the economic and political arenas and induced the economic supremacy of the palatial ranks (Adams, 2009). During Hammurabi's reign, finally, the palace took over many of the temples' economic resources (Van De Mieroop, 2015: 83).

\subsubsection{The institutional role of the military}

The rise of military organizations during the city-states period did not freeze the status quo but induced a further division of the decision-making power whereby the palace jointly organized with the temple farming activities and public good provision (Benati, 2015; Benati and Lecompte, 2020; Prentice, 2010; Richardson, 2011; Rost, 2017). During the kingdoms period, then, new and costly technologies, ${ }^{16}$ such as the war-cart and tin-bronze weapons, together with the increased returns on farming, further empowered the military ranks (Boix, 2015: 132-133; Marchesi and Marchetti, 2011: 203, 213, 216; Richardson, 2011: 18; Wischnewski, 2017: 212-213). Contrary to Boix's (2015) claim however, the palatial households did not crush the other decision-makers, as attested by their cooperation with the temples in the management of economic assets. A case in point is the series of reforms issued by Urukagina, king of Lagash (ca. $2330 \mathrm{BCE}$ ), who, at the same time, reduced the tax-raising power of temples but outsourced to them the control over farming activities in exchange for a steady flow of revenues (Sallaberger, 2018: 184). In a similar manner, in Lagash, even if the digging and maintenance of main watercourses was a royal prerogative, the religious households maintained the control over local irrigation (Rost, 2017: 10). During the empires period, finally, despite the rising costs of armory and incidence of warfare (Foster, 2016: 166-168; Lafont, 2009; Richardson, 2011: 34-39), ${ }^{17}$ palatial ranks favored the enfranchisement of both the merchants and the farmers of the annexed polities (Adams, 2009; Barjamovic, 2018: 128-129; Seri, 2005). Moreover, through the distribution of tenured lands, military conscription turned the soldiers into economic stakeholders with their own collective political power (Richardson, 2011: 20-48).

\footnotetext{
${ }^{15}$ This shift was possibly eased by the introduction of the plow. Given its high maintenance costs, it was affordable only for the elites, who adopted it to obtain a larger surplus from extensive cereal farming (Halstead, 1995).

${ }^{16}$ Four-wheel wagons appeared in Mesopotamia around 3500 BCE (Klimscha, 2017: 37), and they spread in the entire region, from $2750 \mathrm{BCE}$, thanks to the success of the light two-wheel carts (Klimscha, 2017: 37; Rey, 2016: 39).

${ }^{17}$ The importance of the war-cart diminished between the Akkadian period and the mid-second millennium BCE (Abrahami, 2008: 12-13; Lafont, 2009: 16), when the introduction of the spoke wheel and the horse-driven light chariot triggered a major revolution, which determined the empowerment of the cavalry (Klimscha, 2017).
} 


\subsubsection{The institutional role of the merchants}

Contrary to both Acemoglu and Robinson's (2012) and Boix's (2015) idea, the merchants did not simply acquire political power whenever long-distance trades became lucrative. Consistent with our view, this institutional discontinuity was only possible because of the combination of the falling returns on the prevailing farming activities and the unprecedent appeal of long-distance exchanges. To elaborate, during the fourth and third millennia, merchants merely converted, as private entrepreneurs and institutional agents, commodities into wealth without participating in decision-making (Foster, 2016: 180181; Garfinkle, 2010; Wilcke, 2007: 33, 37; Winters, 2019). Similarly, in the Ur III period, merchants were organized into guilds, embedded into the provincial administration of the empire (Garfinkle, 2010: 192-193; Steinkeller, 2004: 97-103). The falling farming returns of the 2000 BCE, together with the unprecedent diffusion of metals, changed this trend (Barjamovic, 2018: 123; Garfinkle, 2010: 186-188; Greenfield, 2013). For the first time, long-distance trades were supported by the institutionalized decision-makers that set up partnerships with the merchant guilds (Adams, 2009; Barjamovic, 2018: 128; Yoffee and Barjamovic, 2018: 816-817) and substituted them for the Ur III administrators (Adams, 2009; Seri, 2005). More important, the merchants did not simply ease the protection of the status quo but championed the organization of a more open social order. Notably, the chamber of affairs - karum - of Sippar not only organized long-distance trade but also supervised, together with the Old Babylonian kings, tax collection, judicial activities, royal granaries, the provision of public buildings and public defense (Harris, 1975: 69-70).

\section{Conclusions}

We have developed a theory of endogenous state formation grounded in the elites' inability to commit to direct transfers and the complementary in group-specific skills, and we have evaluated its implications studying the first recorded forms of stable state institutions observed in Bronze Age Mesopotamia. We close by highlighting three central policy implications of our theory.

First, stronger political and property rights elicit otherwise unattainable cooperation between elites and nonelites only if the skills of the two groups are sufficiently complementary and the return on joint investment is small. Contrary to Acemoglu and Robinson's (2012) view and similar to North et al.'s (2009) conclusion, our framework, then, speaks against the unfettered transplantation of more inclusive political institutions and stronger nonelites' property rights in developing countries. Therefore, cooperation must be elicited by favoring the participation of elites and nonelites to joint investment activities, rather than by limiting skills heterogeneity through human capital accumulation (Boix, 2015) or by assuring the rule of law for the elites and the centralized control over violence (North et al., 2009). Second, complementary skills might induce cooperation even without division of power and, possibly, strong protection of the nonelites' property if joint investment activities are sufficiently profitable. These conclusions disagree with Acemoglu and Robinson's (2012) caution that, even if developed, autocratic regimes must be inefficient, and they are consistent with recent empirical results on the insignificant long-run economic effect of a more inclusive political process (de Oliveira and Guerriero, 2018; Guerriero, 2020). To elaborate, these contributions show that more inclusive political institutions can favor an otherwise unfeasible inter-group cooperation in the short run, but might become irrelevant, if not detrimental, when social and/or technological innovations deprive investment of its role and if not accompanied by a forceful culture of cooperation (Boranbay and Guerriero, 2019). Finally, our analysis entails key policy ramifications for the evaluation of climate change. Although harsh droughts might ease shifts toward more open social orders, less severe ones foster autocratic regimes. These links between climate shocks and institutional evolution must be considered when designing environmental policies.

Acknowledgements. We wish to thank Federico Zaina and Serra Boranbay who coauthored the companion papers on which we build some of our arguments, Zoltan Adam, Luca Andriani, Randolph Bruno, Geoffrey Hodgson, Palmiro Notizia, Seth Richardson, Norman Yoffee and three anonymous readers for insightful comments.

Financial support. The authors acknowledge support by the University of Bologna through the 2017 Alma Idea Grant. 


\section{References}

Abrahami, P (2008), 'L'Armée d'Akkad', in P. Abrahami, and L. Battini (eds), Les Armées Du Proche-Orient Ancien: IIIE-IER Mill. AV. J.-C., Oxford, UK: David Brown Book, pp.1-22.

Acemoglu, D. and J. A. Robinson (2006), Economic Origins of Dictatorship and Democracy, Cambridge, UK: Cambridge University Press.

Acemoglu, D. and J. A. Robinson (2012), Why Nations Fail: The Origins of Power, Prosperity and Poverty, New York: Crown Publisher.

Adams, R. M. (1981), Heartland of Cities. Surveys of Ancient Settlement and Land Use on the Central Floodplain of the Euphrates, Chicago-London: The University of Chicago Press.

Adams, R. M. (2009), 'Old Babylonian Networks of Urban Notables', Cuneiform Digital Library Journal, 2009(7): 1-14.

Ahmed, A and D Stasavage (2020), 'Origins of Early Democracy', American Political Science Review, 114: 502-518.

Alchian, A. A. (1965), 'Some Economics of Property Rights', Il Politico, 30(4): 816-829.

Altaweel, M. (2019), 'Southern Mesopotamia: Water and the Rise of Urbanism', Wiley Interdisciplinary Reviews: Water, 6(4): $1-6$.

Archi, A. (2010), 'Men at War in the Ebla Period. On the Unevenness of the Written Documentation', in A. Kleinerman and J. M. Sasson (eds.), Why Should Someone Who Knows Something Conceal It? Cuneiform Studies in Honor of David I. Owen on His 70th Birthday, Bethesda: CDL Press, pp. 15-35.

Baadsgaard, A., J. Monge, S. L. Cox and R. L. Zettler (2011), 'Human Sacrifice and Intentional Corpse Preservation in the Royal Cemetery of Ur', Antiquity, 85(327): 27-42.

Barjamovic, G. (2018), 'Interlocking Commercial Networks and the Infrastructure of Trade in Western Asia during the Bronze Age', in K. Kristiansen, T. Lindkvist and J. Myrdal (eds.), Trade and Civilisation: Economic Networks and Cultural Ties from Prehistory to the Early Modern Era, Cambridge, UK: Cambridge University Press, pp. 113-142.

Barjamovic, G. and A. S. Fairbairn (2018), 'Anatolian Wine in the Middle Bronze Age', Die Welt des Orients, 48(2): 249-284.

Barzel, Y. (1994), 'The Capture of Wealth by Monopolists and the Protection of Property Rights', International Review of Law and Economics, 14(4): 393-409.

Barzel, Y. and E. Kiser (1991), 'The Origins of Democracy in England', Rationality and Society, 3(4): 396-422.

Benati, G. (2015), 'Re-Modeling Political Economy in Early 3rd Millennium BC Mesopotamia: Patterns of Socio-Economic Organization in Archaic Ur (Tell Al-Muqayyar, Iraq).' Cuneiform Digital Library Journal, 2015(2): 1-37.

Benati, G. (2016), 'High, Low and in Between: Patterns of Bureaucracy, Storage and Mobilization of Resources in Middle Bronze Age (2000-1600 BC) Northern Levant', Studia Eblaitica, 2: 123-176.

Benati, G (2018), 'The Construction of Large-scale Networks in Late Chalcolithic Mesopotamia: Emergent Political Institutions and Their Strategies', in N. Marchetti, and D. Domenici (eds), Urbanized Landscapes in Early SyroMesopotamia and Prehispanic Mesoamerica. Papers of a Cross-Cultural Seminar Held in Honor of Robert McCormick Adams, Wiesbaden: Harrassowitz, pp.103-144.

Benati, G. and C. Guerriero (2020), 'Supplementary Material for "The Origins of the State: Technology, Cooperation and Institutions"', available at https://sites.google.com/site/carmineguerrieroshomepage/home/research-1.

Benati, G. and C. Lecompte (2020), 'The Scale and Extent of Political Institutions in Early Dynastic Mesopotamia: The Case of Archaic Ur', in A. Bramanti, N. Kraus, and P. Notizia (eds), Current Research in Early Mesopotamian Studies, Münster: Zaphon, pp.1-39.

Benati, G., C. Guerriero and F. Zaina (2020), 'The Origins of Political Institutions and Property Rights: Time Inconsistency Vs. Opacity', Working Paper, University of Bologna. doi: 10.2139/ssrn.3395353.

Blanton, R. E. and L. Fargher (2016), How Humans Cooperate. Confronting the Challenges of Collective Action, Boulder, CO: University of Colorado Press.

Boix, C. (2015), Political Order and Inequality, Cambridge, UK: Cambridge University Press.

Boranbay, S. and C. Guerriero (2019), 'Endogenous (In)Formal Institutions', Journal of Comparative Economics, 47(4): 921-945.

Brooke, J. L. (2014), Climate Change and the Course of Global History. A Rough Journey, Cambridge, UK: Cambridge University Press.

Carneiro, R. L. (1970), 'A Theory of the Origin of the State', Science, 169(3497): 733-738.

Charpin, D. (2017), La Vie Méconnue des Temples Mésopotamiens, Paris: Les Belles Lettres, Collège de France.

Childe, V. G. (1936), Man Makes Himself, London: Watts.

Cookson, E., D. J. Hill and D. Lawrence (2019), 'Impacts of Long Term Climate Change during the Collapse of the Akkadian Empire', Journal of Archaeological Science, 106: 1-9.

Cripps, E. (2007), Land Tenure and Social Stratification in Ancient Mesopotamia: Third Millennium Sumer before the UR III Dynasty (BAR S1676), Oxford: Archaeopress.

de Oliveira, G. and C. Guerriero (2018), 'Extractive States: The Case of the Italian Unification', International Review of Law and Economics, 56: 142-159.

Dietler, M. (2005), 'Comments on Jenning et al. "Drinking in a Blissful Mood”', Current Anthropology, 46(2): 289-290. 
Englund, R. K. (1998), 'Texts from the Late Uruk Period', in J. Bauer, R. K. Englund and M. Krebernik (eds.), Mesopotamien: Späturuk-Zeit und Frühdynastische Zeit (Annäherungen 1, Orbis Biblicus et Orientalis 160/1), Göttingen: Vandenhoeck \& Ruprecht, pp. 14-233.

Fleck, R. K. and F. A. Hanssen (2006), 'The Origins of Democracy: A Model with Application to Ancient Greece', Journal of Law and Economics, 49(1): 115-146.

Fleming, D. E. (2004), Democracy's Ancient Ancestors: Mari and Early Collective Governance, Cambridge, UK: Cambridge University Press.

Foster, B. R. (2016), The Age of Agade. Inventing Empire in Ancient Mesopotamia, London-New York: Routledge.

Frangipane, M. (2017), 'The Role of Metallurgy in Different Types of Early Hierarchical Society in Mesopotamia and Eastern Anatolia', in P. Stockhammer and J. Maran (eds.), Appropriating Innovations. Entangled Knowledge in Eurasia, 5000-1500 $B C E$, Oxford: Oxbow Books, pp. 171-183.

Frangipane, M. (2018), 'Different Trajectories in State Formation in Greater Mesopotamia: A View from Arslantepe (Turkey)', Journal of Archaeological Research, 26: 3-63.

Frayne, D (2008), Presargonic Period (2700-2350 BC) (RIME 1), Toronto, CA: University of Toronto Press.

Garfinkle, S. J. (2010), 'Merchants and State Formation in Early Mesopotamia', in S. C. Mellville and A. L. Slotsky (eds.), Opening the Tablet Box. Near Eastern Studies in Honor of Benjamin R. Foster, Leiden-Boston: Brill, pp. 185-202.

Garfinkle, S. J. (2013), 'The Third Dynasty of Ur and the Limits of State Power in Early Mesopotamia', in S. Garfinkle, and M. Molina (eds.), From the 21st Century BC to the 21st Century AD. Proceedings of the International Conference on Neo-Sumerian Studies Held in Madrid, 22-24 July, 2010, Winona Lake, IN: Eisenbrauns, pp. 153-167.

Garfinkle, S. J. (2020), 'Violence and State Power in Early Mesopotamia', in G. G. Fagan, L. Fibiger, M. Hudson, and M. Trundle (eds.), The Cambridge World History of Violence (Vol. I - The Prehistoric and Ancient Worlds), Cambridge, UK: Cambridge University Press, pp. 219-237.

Greenfield, H. J. (2013), “The Fall of the House of Flint”: A Zooarchaeological Perspective on the Decline of Chipped Stone Tools for Butchering Animals in the Bronze and Iron Ages in the Southern Levant', Lithic Technology, 38(3): 161-178.

Guerriero, C. (2016), 'Endogenous Property Rights', Journal of Law and Economics, 59(2): 313-358.

Guerriero, C. (2019), 'Property Rights, Transaction Costs, and the Limits of the Market.' Working paper, University of Bologna. doi: 10.2139/ssrn.3058095.

Guerriero, C. (2020), 'Endogenous Institutions and Economic Outcomes', Economica, 87(346): 364-405.

Halstead: (1995), 'Plough and Power: The Economic and Social Significance of Cultivation with the Ox-Drawn Ard in the Mediterranean', Bulletin on Sumerian Agriculture, 8: 11-22.

Hamblin, W. J. (2006), Warfare in the Ancient Near East to 1600 BC. Holy Warriors at the Dawn of History, London: Routledge.

Harris, R. (1975), Ancient Sippar. A Demographic Study of an Old-Babylonian City (1894-1595 B.C.) (PIHANS 36), Leiden: Nederlands Historisch-Archaeologisch Instituut te Istanbul.

Hodgson, G. M. (2015), 'Much of the "Economics of Property Rights" Devalues Property and Legal Rights', Journal of Institutional Economics, 11(4): 683-709.

Hole, F (1994), 'Environmental Instability and Urban Origins', in G. J. Stein, and M. S. Rothman (eds), Chiefdoms and Early States in the Near East: The Organizational Dynamics of Complexity (Monagraphs in World Prehistory 18), Madison, WI: Prehistory Press, pp.121-152.

Klimscha, F. (2017), 'Transforming Technical Know-How in Time and Space. Using the Digital Atlas of Innovations to Understand the Innovation Process of Animal Traction and the Wheel', eTopoi, 6: 16-63.

Lafont, B. (2009), 'The Army of the Kings of Ur: The Textual Evidence', Cuneiform Digital Library Journal, 5: 1-25.

Liverani, M. (2006), Uruk, The First City, London-Oakville, CT: Equinox.

Liverani, M. (2014), The Ancient Near East. History, Society, Economy, London: Routledge.

Steinkeller: and M. Hudson, (eds.) (2015), Labor in the Ancient World (The International Scholars Conference on Ancient Near Eastern Economies, 5), Dresden: ISLET-Verlag.

Marchesi, G. and N. Marchetti (2011), The Royal Statuary of Early Dynastic Mesopotamia, Winona Lake, IN: Eisenbrauns.

Matthews, R. J. and A. Richardson (2018), 'Cultic Resilience and Inter-City Engagement at the Dawn of Urban History: Protohistoric Mesopotamia and the "City Seals", 3200-2750 BC', World Archaeology, 50(5): 723-747.

McMahon, A. (2014), 'State Warfare and Pre-State Violent Conflict: Battle's Aftermath at Late Chalcolithic Tell Brak', in H. E. W. Crawford and A. McMahon (eds.), Preludes to Urbanism. The Late Chalcolithic of Mesopotamia, Cambridge, UK: McDonald Institute for Archaeological Research, pp. 175-189.

McMahon, A. (2020), 'Early Urbanism in Northern Mesopotamia', Journal of Archaeological Research, 28: 289-337.

Miller, N. F. (2008), 'Sweeter than Wine? The Use of the Grape in Early Western Asia', Antiquity, 82(318): 937-946.

Myerson, R. B. (2008), 'The Autocrat's Credibility Problem and Foundations of the Constitutional State', American Political Science Review, 102(1): 125-139.

North, D. C. and B. R. Weingast (1989), 'Constitutions and Commitment: The Evolution of Institutions Governing Public Choice in Seventeenth-Century England', Journal of Economic History, 49(4): 803-832.

North, D. C., J. J. Wallis and B. R. Weingast (2009), Violence and Social Orders: A Conceptual Framework for Understanding Recorded Human History, Cambridge, UK: Cambridge University Press. 
Palmisano, A. (2018), The Geography of Trade. Landscapes of Competition and Long-Distance Contacts in Mesopotamia and Anatolia in the Old Assyrian Colony Period, Oxford: Archaeopress.

Postgate, J. N. (1992), Early Mesopotamia: Society and Economy at the Dawn of History, London: Routledge.

Powell, M. A. (1996), 'Wine and the Vine in Ancient Mesopotamia: The Cuneiform Evidence', in P. E. McGovern, S. J. Fleming, and S. H. Katz (eds), The Origins and Ancient History of Wine, Amsterdam: Gordon \& Breach, pp. 97-122.

Prentice, R. (2010), The Exchange of Goods and Services in Pre-Sargonic Lagaš (AOAT 368), Münster: Ugarit Verlag.

Renger, J. M. (1995), 'Institutional, Communal, and Individual Ownership or Possession of Arable Land in Ancient Mesopotamia from the End of the Fourth to the End of the First Millennium B.C.', Chicago-Kent Law Review, 71(1): 269-319.

Rey, S. (2016), 'Mesopotamian Poliorcetics Before Assyria: Genesis of the Art of Fortification and Siege Warfare', in R. Frederiksen, S. Müth, P. Schneider, M. Schnelle (eds), Focus on Fortification: New Research on Fortifications in the Ancient Mediterranean and the Near East, Oxford: Oxbow Books, pp. 34-42.

Richardson, S. (2011), 'Mesopotamia and the "New" Military History', in L. L. Brice and J. T. Roberts (eds.), Recent Directions in the Military History of the Ancient World, Claremont, CA: Regina Books, pp. 11-51.

Richardson, S. (2012), 'Early Mesopotamia: The Presumptive State', Past \& Present, 215(1): 3-49.

Richardson, S. (2016), 'Insurgency and Terror in Mesopotamia', in T. Howe and L. L. Brice (eds.), Brill's Companion to Insurgency and Terrorism in the Ancient Mediterranean, Leiden-Boston: Brill, pp. 31-61.

Richardson, S. and S. J. Garfinkle (2020), 'Community Violence in Middle Bronze Age Mesopotamia', in V. Juloux, and L. Pace (eds), A Study of Violence in the Ancient Near East and its Neighbors, Leiden-Boston: Brill, pp. 1-56.

Riehl, S., K. E. Pustovoytov, H. Weippert, S. Klett and F. Hole (2014), 'Drought Stress Variability in Ancient Near Eastern Agricultural Systems Evidenced by $\Delta 13 \mathrm{C}$ in Barley Grain', Proceedings of the National Academy of Sciences of the United States of America, 111(34): 12348-12353.

Ristvet, L. (2017), 'Assyria in the Third Millennium BCE', in E. Frahm (ed.), A Companion to Assyria, New York: Wiley-Blackwell, pp. 36-56.

Rost, S. (2017), 'Water Management in Mesopotamia from the Sixth till the First Millennium B.C.', Wiley Interdisciplinary Reviews: Water, 4(5): 1-23.

Sallaberger, W. (2018), 'Festival Provisions in Early Bronze Age Mesopotamia', Kaskal, 15: 171-200.

Sallaberger, W. (2019), 'Who Is Elite? Two Exemplary Cases From Early Bronze Age Syro-Mesopotamia', in G. Chambon, M. Guichard, and A.-I. Langlois (eds.), De l'argile au numérique. Mélanges assyriologiques en l'honneur de Dominique Charpin (Publications de l'Institut du Proche-Orient Ancien du Collège de France 3), Leuven, Paris, Bristol: Peeters, pp. 893-921.

Sallaberger, W. and I. Schrakamp (2015), 'Part 1: Philological Data for a Historical Chronology of Mesopotamia in the 3rd Millennium', in W. Sallaberger and I. Schrakamp (eds.), ARCANE III. History and Philology, Turnhout: Brepols, pp. 1-136.

Schrakamp, I. (2010), Krieger und Waffen im frühen Mesopotamien. Organisation und Bewaffnung des Militärs in frühdynastischer und sargonischer Zeit, Marburg, PhD Dissertation. doi: 10.17192/z2010.0486.

Seri, A. (2005), Local Power in Old Babylonian Mesopotamia, London: Equinox.

Smith, M. E., T. A. Kohler and G. M. Feinman (2018), 'Studying Inequality's Deep Past', in T. A. Kohler and M. E. Smith (eds.), Ten Thousand Years of Inequality. The Archaeology of Wealth Differences, Tucson, AZ: University of Arizona Press, pp. 3-38.

Sołtysiak, A. (2015), 'Antemortem Cranial Trauma in Ancient Mesopotamia', International Journal of Osteoarchaeology, 27(1): 119-128.

Staubwasser, M. and H. Weiss (2006), 'Holocene Climate and Cultural Evolution in Late Prehistoric-Early Historic West Asia', Quaternary International, 66(3): 372-387.

Steinkeller, P (1999), 'Land-Tenure Conditions in Third Millennium Babylonia: The Problem of Regional Variation', in M. Hudson, and B. A. Levine (eds), Urbanization and Land Ownership in the Ancient Near East, Cambridge, MA: Peabody Museum, Harvard University, pp.289-321.

Steinkeller: (2004), 'Toward a Definition of Private Economic Activity in Third Millennium Babylonia', in R. Rollinger, C. Ulf, K. Schnegg (eds.), Commerce and Monetary Systems in the Ancient World: Means of Transmission and Cultural Interaction (Melammu Symposia 5), Stuttgart: Franz Steiner, pp. 91-111.

Steinkeller: (2013), 'An Archaic “Prisoner Plaque” from Kiš', Revue d'assyriologie et d'archéologie Orientale, 107: 131-157.

Steinkeller: (2018), 'The Reluctant En of Inana or the Persona of Gilgameš in the Perspective of Babylonian Political Philosophy', Journal of Ancient Near Eastern History, 5(1-2): 149-177.

Steinkeller: (2019), 'Babylonian Priesthood during the Third Millennium BCE: Between Sacred and Profane', Journal of Ancient Near Eastern Religions, 19(1-2): 112-151.

Tylecote, A. (2016), 'Institutions Matter: But Which Institutions? And How and Why Do They Change?', Journal of Institutional Economics, 12(3): 721-742.

Van De Mieroop, M. (2015), 'Production and Commerce in the Old Babylonian Period', Rivista di Storia Economica, 31(1): 79-96.

Weiss, H. (2017), '4.2 ka BP Megadrought and the Akkadian Collapse', in H. Weiss (ed.), Megradrought and Collapse. From Early Agriculture to Angkor, Oxford: Oxford University Press, pp. 93-160. 
Westbrook, R (2003) 'Old Babylonian Period', in R. Westbrook (ed), A History of Ancient Near Eastern Law, Boston, MA: Brill, pp.361-430.

Widell, M., C. Hritz, J. Ur and T. J. Wilkinson (2013), 'Land Use of the Model Communities', in T. J. Wilkinson, M. G. Gibson, and M. Widell (eds.), Models of Mesopotamian Landscapes. How Small-Scale Processes Contributed to the Growth of Early Civilizations, Oxford, UK: Archaeopress, pp. 56-80.

Wilcke, C. (2007), Early Ancient Near Eastern Law. A History of Its Beginnings: The Early Dynastic and Sargonic Periods (2nd edn), Winona Lake, IN: Eisenbrauns.

Wilkinson, T. J., L. Rayne and J. Jotheri (2015), 'Hydraulic Landscapes in Mesopotamia: The Role of Human Niche Construction', Water History, 7: 397-418.

Winters, R. D. (2019), Negotiating Exchange: Ebla and the International System of the Early Bronze Age, Harvard, PhD Dissertation. Available at http://nrs.harvard.edu/urn-3:HUL.InstRepos:41121311.

Wischnewski, U. (2017), 'Appropriation of Tin-Bronze Technology: A Regional Study of the History of Metallurgy in Early Bronze Age Southern Mesopotamia', in P. Stockhammer and J. Maran (eds.), Appropriating Innovations. Entangled Knowledge in Eurasia, 5000-1500 BCE, Oxford-Philadelphia: Oxbow Books, pp. 211-219.

Yoffee, N. (2005), Myths of the Archaic State. Evolution of the Earliest Cities, States, and Civilizations, Cambridge, UK: Cambridge University Press.

Yoffee, N. and G. Barjamovic (2018), 'Old Assyrian Trade and Economic History', in S. Paulus, K. Kleber and G. Neumann (eds.), Grenzüberschreitungen. Studien zur Kulturgeschichte des Alten Orients. Festschrift für Hans Neumann Anlässich Seines 65, Münster: Zaphon, pp. 815-824.

Yoffee, N. and A. Seri (2019), 'Negotiating Fragility in Ancient Mesopotamia: Arenas of Contestation and Institutions of Resistance', in N. Yoffee (ed.), The Evolution of Fragility: Setting the Terms, Cambridge, UK: Cambridge University Press, pp. 183-196.

Ziegler, N. (2008), 'Samsî-Addu et ses soldats', In P. Abrahami and L. Battini (eds.), Les armées du Proche-Orient ancien (BAR S1855), Oxford: Archaeopress, pp. 49-56.

Cite this article: Benati G, Guerriero C (2020). The origins of the state: technology, cooperation and institutions. Journal of Institutional Economics 1-15. https://doi.org/10.1017/S1744137420000569 